\title{
Development of "Tayoga" Video to Improve Body Fitness and Sensitivity in Covid-19 Prevention
}

\author{
I Nengah Mariasa ${ }^{1, *}$ Noordiana $^{1,}$ Retnayu P. Sekti ${ }^{1,}$ Enie W. Handayani ${ }^{1,}$
}

\author{
Budi Dharmawanputra ${ }^{1}$
}

\author{
${ }^{1}$ Faculty of Languages and Arts, Universitas Negeri Surabaya, Indonesia \\ ${ }^{*}$ Corresponding author: mariasa@unesa.ac.id
}

\begin{abstract}
Since the beginning of March 2020, the number of positive cases of the 2019 coronavirus disease (Covid-19) has continued to increase. Until Wednesday (1/4/2020), the number of positive cases of Covid-19 reached 1,677. There were 103 patients who were declared cured and 157 other patients died. Over the 17 days from April 1 to April 18 confirmed cases increased by 4545 from 1,677 to 6,222, likewise the number of people who died increased by 378 from 157 to 535 . A number of procedures have been carried out by the government to overcome the spread of the corona virus in Indonesia. Unesa as part of the government which is engaged in education took part in overcoming the spread of the corona virus. In the field of research making policy so that lecturers carrying out research contribute to overcoming the case. We as dance researchers are aware that this need is very encouraging to take part in preventing corona virus outbreaks. A type of fitness exercise that has been very popular that can improve fitness and respiratory health is yoga. In general yoga is interpreted as a fitness gymnastics, but actually it's not as narrow as it means. Yoga is divided into eight levels called astanga yoga, namely: 1) yama, 2) niyama, 3) asanas, 4) pranayama, 5) pratihara, 6) dharana, 7) dhyana, and 8) samadhi. Yama niyama functions to form the character of dharma, asanas functions to increase endurance, pranayama to increase the power of breathing, pratihara-dharana-dhyana-samadhi builds the power of meditation that leads to the power of concentration. Dance and yoga when collaborated will produce a dance choreography that is unique to health. The specific objectives of this study are: to describe the process of developing the Tayoga video; to describe the development quality of Tayoga video; and describes the effectiveness of developing Tayoga videos based on user responses and learning outcomes. This study uses the Research and Development (R \& D) method with the Four-D development model from Thiagarajan. The research procedure is divided into four parts, namely: define, design, development, disseminate. The conclusions of this paper are 1) although there are obstacles the development process is running smoothly. The development process is carried out based on the development parts that have been compiled; 2) the value of the quality of the development content is $91.06 \%$ and the media presentation is $94.44 \%$, which means that this product is very suitable for use; 3 ) the value in the small-scale trial was $87.81 \%$, while the large-scale trial was $88.05 \%$, which means that this video was effectively used.
\end{abstract}

Keywords: Tayoga, Yoga-dance, Yoga choreography, Asanas dance

\section{INTRODUCTION}

Since early March 2020, the number of positive cases of coronavirus disease 2019 (Covid-19) has continued to increase. Until Wednesday (1/4/2020), the number of positive cases of Covid-19 reached 1,677. There were 103 patients who were declared cured and 157 other patients died. [1] That is information on April 1, 2020, while the increase in Covid-19 cases to April 18 2020 is as follows.
During 17 days from April 1 to April 18, confirmed cases increased by 4545 from 1,677 to 6,222 , as well as people who died increased by 378 from 157 to 535 . Surabaya is still the worst Covid-19 case area in East Java with positive cases reaching 250 people. [2]

Unesa as part of the government engaged in education is taking part in overcoming the spread of the corona virus. In the field of research, make a policy so that the lecturers carry out research to take part in 
solving the case. As a researcher in dance, I realize that this need is very encouraging to take part in preventing the spread of the corona virus.

The type of health exercise that is very popular today that can improve fitness and respiratory health is yoga. In general, yoga is interpreted as a fitness exercise, but the meaning is not that narrow. Yoga is divided into eight levels which are called astanga yoga.

If collaborated, dance and yoga will produce a unique dance choreography for health. This research will try to make a dance choreography product which is a combination of yoga and dance that can be used by the community to increase fitness and body sensitivity in preventing Covid-19.

The specific objectives of this study are: (1) to describe the process of developing the Tayoga dance video to improve fitness and body sensitivity in preventing Covid-19, (2) to describe the quality of the development of the Tayoga dance video to improve fitness and body sensitivity in preventing Covid-19, and (3) to describe the effectiveness of developing the Tayoga dance video to improve fitness and body sensitivity in the prevention of Covid-19, based on user responses and learning outcomes.

\section{METHOD}

\subsection{Choreography}

In dance, choreography has two meanings, namely: first, choreography is the knowledge of dance composition which involves the work process of how to make dance; second, choreography is dance as a result of artistic creation, the result of a dance form. The artist who creates or arranges the dance is called a choreographer. [3]

There are two values for the beauty of art forms, namely subjective value and objective value. [4] This creation would be more appropriate if approached with a subjective artistic approach, given that the product of yoga-dance development is aimed at the general public who have amateur dance knowledge and skills. Dance products should be adapted to users who generally do not have an academic dance education. The tendency of general observers to be more pragmatic, so that it is easier for them to understand the art forms that are more familiar to them.

Elizabeth R. Hayes stated ten artistic principles of form, namely: unity, variety, repetition, contrast, transition, sequence, climax, proportion, balance, and harmony. [5] These elements are the defining elements of the artistic choreography. Each of these artistic elements supports one another. In this creation the concept that is emphasized more is unity, balance and harmony.

There are five theme tests that were expressed by La Meri in choosing a dance theme to be presented. The five theme tests are: 1) the choreographer's belief in the value of the theme; 2 ) can the theme be danced; 3 ) the instantaneous effect of the theme on the audience is favorable. 4) equipment for dance techniques from creators and dancers; 5) the necessary facilities for the performance, for example: space, lighting, costumes, music and so on. [6] The five tests underlie the determination of the theme in this development research. In addition, in making dance creations, logic or scientific concepts are used in arranging a series of creations. This is supported by the statement that the construction method of a dance composition is very important considering its logical development. The concept of syllogism is also a fundamental aspect that becomes a consideration in composing Tayoga dance movements. [7]

The design of symmetry is more calm, peaceful, strong, and constructive, while the design of asymmetry has a stimulating and more dynamic impression. [8] These two concepts are used to underlie this creation of products to match expectations.

\subsection{Yoga}

According to Patanjali's teachings, yoga is divided into eight which is called astanga yoga. Astanga yoga is eight levels of yoga consisting of: 1) yama, 2) niyama, 3) asanas, 4) pranayama, 5) pratihara, 6) dharana, 7) dhyana, and 8) samadhi. Yama, is a teaching about good attitude which consists of five teachings of self-control, namely: 1) ahimsa, 2) satya, 3) asteya, 4) aparigraha, and 5) brahmacarya. Niyama, is an attitude of selfcontrol to purify one's soul which consists of: 1) sauca, 2) sentosa, 3) tapa, 4) swadhyaya, 5) Iswara Pranidhana. [9]

Asanas, which are relaxed body postures, are a very scientific system developed thousands of years ago by Yogi. Practicing regular and disciplined asanas can improve blood circulation, relax joints, strengthen muscles and massage and stimulate the internal organs. By practicing asanas, not only can the health of the body be maintained but also help to calm and control the soul. 
If asanas are practiced regularly, one will be able to accumulate a myriad of "inner energy" which can increase endurance, nourish body and spirit. [10]

Pranayama is the fourth level of astanga yoga which emphasizes regulating or processing the breath to regulate the prana (energy) that enters the body. Breath as prana that enters the body should be controlled so that it is more focused, aimed at the awakening of the chakras in the body. Pranayama techniques are divided into three, namely puraka (inhaling), kumbhaka (holding breath) and recaka (exhaling). If you practice proper and regular pranayama the whole body will be filled with vital prana. After that the whole body comes under our control and all diseases can be destroyed at the root. [11]

Pratyahara, is meditation at the first level, namely the ability to control the senses from their object attachments. A person who has been able to do pratyahara is a person who is unable to function his senses during meditation, for example, he does not hear the sound around him, he does not feel bitten by ants, the hot air cannot affect him, no longer smells odors, etc. senses.

Dharana, is the second level of meditation, namely efforts to unite the mind with the desired object. The mind has focused on towards one object.

Dhyana, is the third level of meditation, namely the concentration of the mind that leads to a higher level. Something that is aimed cannot be put into words, because something that is being aimed at is far beyond words, so here it can only be said as a calm for those who reach it.

Samaddhi, is the last level of meditation, the union of atman (the true self) with Brahman (God). Very rarely do people reach the level of samadhi.

In this research, yoga will be emphasized on two basic parts, namely yoga asanas and pranayama. The product in the form of dance was created on the basis of the concepts of yoga asanas and pranayama. Some of the yoga asanas movements which are the main source of development are the suryanamaskara movements which consist of pranamasana, hasta uttanasana, padahastasana, asva sancalanasana, parvatasana, astanga namaskara and bujangasana movements.[12] Besides that, other yoga asanas movements are also used, namely diirgha pranama, tadasana, vrikshasana, virabhadrasana, marjariasana.

\subsection{Audio Visual Learning Media}

Using audio-visual technology in learning is very good at improving students' learning abilities by $50 \%$ compared to without using media. This is consistent with Vernom's statement, where learning only comes from reading will store $10 \%$ information; learning by relying on the sense of hearing for information absorbs only $20 \%$; obtaining information from what the eye sees absorbs only $30 \%$; utilizing the senses of sight and hearing in learning only absorb 50\%; get information through what is said to be able to absorb $70 \%$ and $90 \%$ of what has been done. [13]

This statement is also in accordance with the characteristics of audio-visual media which are not limited by distance and time, there is repetition of the material being studied as needed, the process of delivering the material presented is faster and easier to remember, and audio-visual media can be used by all students.[14 ] In developing audio-visual learning media, it is necessary to pay attention to the quality criteria which include several things, namely: the video can run well; the display of video media is interesting to see; the material in the video is presented clearly, easily, and systematically; accuracy in determining the display, location and other supporting elements; and video content in accordance with development goals.

The concept of audio-visual media is used to help provide an understanding of the benefits of using auidovisual media and determine and analyze learning media.

\subsection{Development Method}

This type of research is development research. Development research methods are methods used to produce certain products, and test the practicality and effectiveness of the product. [15] This research will produce a video product to learn to dance Tayoga.

The model in this development research used the Thiagarajan Four-D development model which consists of 4 parts, namely Define, Design, Develop, Dessiminate. [16]

Define, the researcher explores the yoga asanas movements both on the internet and the author's experience in learning asanas yoga. In addition, he also carried out internet studies on techniques of strengthening the thymus gland for immune formation.

Design, this research produces a physical product in the form of six video files, each of which is four video 
presentations and two video tutorials. The four presentation videos consist of one complete presentation video of "Tari Tayoga", one identification presentation, namely "Deskripsi Tari Tayoga", one presentation video of "Ragam Gerak Tari Tayoga", and one video presentation of "Evaluasi Tari Tayoga". Furthermore, two video tutorials are one video tutorial, namely "Teknik Gerak dan Pernafasan Tari Tayoga," and a video tutorial "Meniru Gerak Tari Tayoga."

Develop, the development section is carried out in three parts, namely product validation, revision, and product testing. Content design validation on yoga concepts and materials was carried out by a yoga expert, namely Dr. Setiawan, M.Hum. Media and graphic validation were carried out by a media expert, namely Dr. H. Andi Mariono, M.Pd. Revisions are made based on suggestions and input from the validator. Furthermore, after going through the revision step the second draft of the video was tried out in a limited or small group. In the limited trial, research was carried out on 10 people in the 2018C Dance Composition class, while the large-scale test was carried out in three classes, namely 2018c Dance Composition; Pancasila Education Class 2019a; and the 2019b Pancasila Education class, Sendratasik Department, FBS Unesa Surabaya. Likewise, revisions were also made after carrying out large-scale trials.

Disseminate, for the distribution of the product is done by creating a link on YouTube. The link is then socialized to groups or also to organizations.

\section{RESULTS AND DISCUSSION}

\subsection{The Tayoga Dance Video Development Process}

\subsubsection{Define}

Researchers explored the yoga asanas movements both on the internet and the author's experience in learning suryanamaskara and yoga asanas. In addition, he also carried out internet studies regarding the technique of punching the chest and breathing motion pranamasana which can strengthen the thymus gland for immune formation. Next, explore the movements of suryanamaskara and several other yoga asanas, namely diirgha pranama, tadasana, virabhadrasana, vrikshasana and marjariasana.

\subsubsection{Random Forest}

Six planned video products have been created as the first design video products. The first design video made is as follows.

(1) The Video "Tari Tayoga," (Tayoga Dance)

(2) The Video "Deskripsi Tari Tayoga," (Description of Tayoga Dance)

(3) The Video "Ragam Gerak Tari Tayoga," (Types of Tayoga Dance Movements)

(4) The Video "Teknik Gerak dan Pernafasan Tari Tayoga," (Movement and Breathing Techniques of Tayoga Dance)

(5) The Video "Meniru Gerak Tari Tayoga" (Imitating Tayoga Dance Movements)

(6) The Video "Evaluasi Tari Tayoga" (Evaluation of Tayoga Dance)

The first video "Tari Tayoga" has a duration of 11 minutes 13 seconds, contains two parts. The first part is the appearance of the Unesa logo and writing "LEMBAGA PENELITIAN DAN PENGABDIAN KEPADA MASYARAKAT (LPPM) UNIVERSITAS NEGERI SURABAYA."

Furthermore, the presentation of the introductory remarks from the Chief Researcher contains an invitation to perform the Tayoga dance. The introductory presentation can be seen in the following picture.

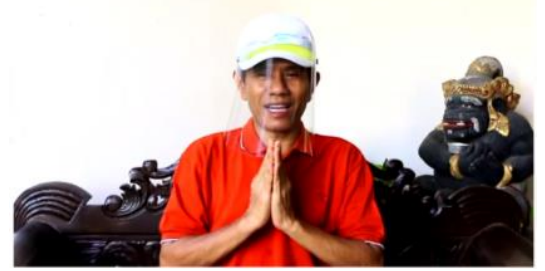

Figure 1. Introduction to the first part of the video presentation "Tari Tayoga." (Foto: Dhana)

The second part contains the full video of the Tayoga dance in front. This dance is divided into five parts. The first is a warm-up motion that is filled with regular running movements to form a circle floor pattern, then the floor pattern forms the letter S. Second is a decrease or recovery movement that is filled with stretching the knee muscles, waist muscles, and neck muscles. The third part is the movement of jogedan 1 with moderate then slow rhythm. The fourth part is the movement of 
jogedan 2 with a rhythm of $2 / 4$. The fifth part is jogedan 3 is still in $2 / 4$ rhythm. The sixth part is jogedan 4 returns to slow rhythm. The seventh part of jogedan 5 returns to rhythm $2 / 4$.

The process of designing the Tayoga dance is carried out by discussing and improvising exploring the movements with three female dancers. The three dancers consist of two students of the Sendratasik Education Program, FBS Unesa and one dancer from the Bale Agung Surabaya Group. The pictures of the training process with three dancers are as follows.

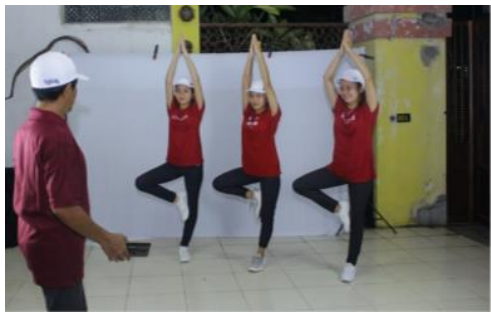

Figure 2 The process of practicing the vrikshasana movements. (Foto: Sringatin)

Tayoga's movement and music were created at the same time. The choreographer develops movement motives down to sentences and phrases of movement sentences, then the composer responds to the existing movements and then immediately improvises to create the dance music. This process is preceded by compromise and unifying opinions so that the creative design is quickly worked out. The music used is digital music, which is made up of music that is done by processing or composing melodies, rhythms, and harmonies on the computer. The basic notes used for this choreography are pentatonic notes. The picture of the process of making Tayoga dance music is as follows.

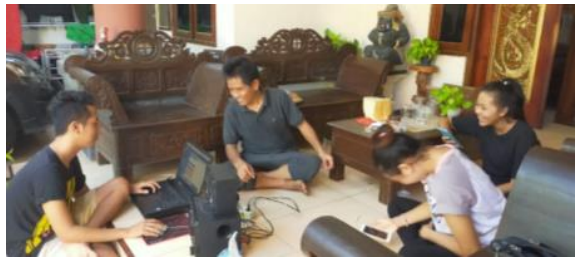

Figure 3 The process of making Tayoga dance music. (Foto: Sringatin)

The second video "Deskripsi Tari Tayoga" has a duration of 8 minutes. This description contains the design and production identification. The design of the creation contains a description of the title, purpose, benefits, and location of the activity. The production identification contains the production team, that is, the presentation of the names involved in the production of the creation.

The third video "Ragam Gerak Tari Tayoga" has a duration of 11 minutes and 3 seconds. This video contains the names of the types of movements and the presentation of each type of movement. Besides that, there is a presentation of the type of movement that is slowed down. The type of movement that is slowed down is aimed at the type of movement that is difficult for beginner dancers, namely the ayun tranjal movement. There are 39 types of Tayoga dance movements.

The fourth video, "Teknik Gerak dan Pernafasan Tari Tayoga" has a duration of 7 minutes. This video contains an explanation of how to move well to practice the Tayoga dance. In addition to an explanation of movement techniques, it also emphasizes how to do breathing techniques in practicing the Tayoga dance

The fifth video "Meniru Gerak Tari Tayoga" has a duration of 9 minutes 45 seconds. This video contains a complete presentation of the Tayoga dance from behind. This presentation is done to make it easier to imitate the movements of the Tayoga dance, especially for dancers who have not been able to imitate the movements with the ngede system.

The sixth video "Evaluasi Tari Tayoga" has a duration of 1 minute 11 seconds. This video contains a written explanation of how to evaluate yourself to find out the suitability of the motion that has been done with the video being studied.

\subsubsection{Development}

The initial design that had been made was validated by two teams of experts, one material expert and one graphic-media expert. There are no revisions regarding the material in this product, while there is a revised graphic regarding the presentation locations. Thus, the background for the presentation of this product is revised into an open environment, with good sunlight. After the revision is complete, then a product trial is carried out

During this covid period, product trials were carried out online. First, small-scale product trials were carried out on 10 students in the 2018 Dance Composition class.

Small-scale trials were carried out until the first revision process resulted in video product I. 
Next, a large-scale online trial was conducted on 45 students spread across three 2018c Dance Composition classes; Pancasila Education Class 2019a; and the 2019b Pancasila Education class, Sendratasik Department, FBS Unesa Surabaya.

Large-scale trials were carried out until the second revision process resulted in video product II. Then a video is compiled as the final teaching material.

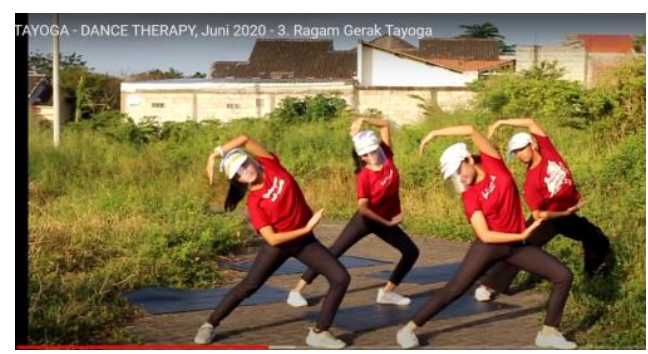

Figure 4 One example of Video II after the revision

\subsubsection{Disseminate}

In the dissemination parts, researchers began to duplicate the product, then socialized it to a wider network via YouTube. The links referred to for this development product are as follows.

Video Link "Tari Tayoga," https://www.youtube.com/watch?v=E5Y5fY2boOw

Video Link "Deskripsi Tari Tayoga," https://www.youtube.com/watch?v=NXJg4pOob-8

Video Link "Ragam Gerak Tari Tayoga," https://www.youtube.com/results?search_query=tayoga+ dance

Video Link "Teknik Gerak dan Pernafasan Tari Tayoga,"

https://www.youtube.com/watch?v=LLCQfXetKYo\&t= $21 \mathrm{~s}$

Video Link "Meniru Gerak Tari Tayoga" https://www.youtube.com/watch?v=D82mcHq9Alo

Video Link "Evaluasi Tari Tayoga" https://www.youtube.com/watch?v=N9sBzPoo29I\&list= PLQP8AImroW8RDBTJm3_JO7eKMs9jHQpyL

The link is then socialized to groups of dance and gymnastics teaching teachers. The following was also carried out by the organization of the Indonesian Hindu Dharma Women (WHDI) Karangpilang Surabaya.

\subsection{Quality of Tayoga Dance Video Development}

The quality of the development of this video is determined by the results of the validation provided by material content experts and media presentation experts. The results of material content validation can be seen in the following table.

Table 1. Validation results of the contents of the development of tayoga dance video from setiawan validators

\begin{tabular}{|c|c|c|c|}
\hline \multirow[t]{2}{*}{ No. } & \multirow[t]{2}{*}{ Indicator } & \multicolumn{2}{|c|}{ Result } \\
\hline & & $\begin{array}{c}\text { Video } \\
1\end{array}$ & $\begin{array}{c}\text { Video } \\
2\end{array}$ \\
\hline 1. & $\begin{array}{l}\text { The quality of the presentation } \\
\text { of the pranamasana and hasta } \\
\text { uttanasana movements. }\end{array}$ & 3 & 3 \\
\hline 2. & $\begin{array}{l}\text { The quality of the presentation } \\
\text { of the } \\
\text { padahastasana dan asva } \\
\text { sancalanasana movements. }\end{array}$ & 3 & 3 \\
\hline 3. & $\begin{array}{l}\text { The quality of the presentation } \\
\text { of the parvatasana, and } \\
\text { astanga namaskara } \\
\text { movements. }\end{array}$ & 3 & 4 \\
\hline 4. & $\begin{array}{l}\text { The quality of the presentation } \\
\text { of the bujangasana and diirgha } \\
\text { pranama movements. }\end{array}$ & 4 & 4 \\
\hline 5. & $\begin{array}{l}\text { The quality of the presentation } \\
\text { of the tadasana and } \\
\text { vrikshasana movements. }\end{array}$ & 4 & 4 \\
\hline 6. & $\begin{array}{l}\text { The quality of the presentation } \\
\text { of the } \\
\text { virabhadrasana and } \\
\text { marjariasana movements. }\end{array}$ & 4 & 4 \\
\hline 7. & $\begin{array}{l}\text { The clarity of the content in the } \\
\text { video. }\end{array}$ & 4 & 4 \\
\hline & Total & 25 & 26 \\
\hline & Percentage & 91,0 & \\
\hline
\end{tabular}

Note Result:

$1=$ less $; 2$ = moderate 3 = good 4 = very good 
$0-20 \%=$ Not feasible $; 21-40 \%=$ less feasible; $41-60 \%=$ Fairly feasible; $61-80 \%=$ Eligible; $81-100 \%=$ Very feasible

The result of the quality value of the content of development materials is $91.06 \%$, which means that the product in terms of this material is very suitable for use.

The results of the quality value of the media presentation by Andi Mariono are $94.44 \%$, which means that the product in terms of media is very suitable for use.

\subsection{The Effectiveness of the Tayoga Dance Video Development}

The data used to measure the effectiveness of this video development are student response data and learning outcomes of the Tayoga dance presentation. The small-scale trial was conducted on 10 students who were taken randomly, and the large-scale test was carried out on 45 students who were taken randomly.
Table 2. Test results trial the small scale of tayoga dance video development

\begin{tabular}{|c|c|c|c|c|c|c|c|c|c|c|}
\hline \multirow{2}{*}{$\begin{array}{l}\mathrm{N} \\
\mathrm{O} .\end{array}$} & \multirow[t]{2}{*}{ NIM } & \multicolumn{8}{|c|}{ Indicator Item Values } & \multirow{2}{*}{$\begin{array}{l}\text { Scor } \\
\text { e }\end{array}$} \\
\hline & & 1 & 2 & 3 & 4 & 5 & 6 & 7 & 8 & \\
\hline 1. & $\begin{array}{l}180201340 \\
04\end{array}$ & 3 & 4 & 4 & 4 & 4 & 4 & 4 & 4 & 31 \\
\hline 2. & $\begin{array}{l}180201340 \\
34\end{array}$ & 4 & 4 & 4 & 4 & 3 & 3 & 3 & 4 & 29 \\
\hline 3. & $\begin{array}{l}180201340 \\
49\end{array}$ & 3 & 3 & 3 & 3 & 4 & 3 & 3 & 4 & 24 \\
\hline 4. & $\begin{array}{l}180201340 \\
25\end{array}$ & 3 & 3 & 4 & 4 & 4 & 4 & 3 & 4 & 29 \\
\hline 5. & $\begin{array}{l}180201340 \\
87\end{array}$ & 3 & 3 & 3 & 3 & 3 & 3 & 3 & 3 & 24 \\
\hline 6. & $\begin{array}{l}180201340 \\
39\end{array}$ & 3 & 4 & 4 & 4 & 3 & 4 & 3 & 4 & 29 \\
\hline 7. & $\begin{array}{l}180201340 \\
06\end{array}$ & 3 & 4 & 3 & 3 & 3 & 4 & 3 & 4 & 27 \\
\hline 8. & $\begin{array}{l}180201340 \\
08\end{array}$ & 3 & 4 & 3 & 3 & 4 & 4 & 3 & 4 & 28 \\
\hline 9. & $\begin{array}{l}180201340 \\
62\end{array}$ & 4 & 3 & 4 & 4 & 4 & 4 & 4 & 4 & 31 \\
\hline 10. & $\begin{array}{l}180201340 \\
92\end{array}$ & 3 & 4 & 3 & 4 & 4 & 4 & 3 & 4 & 29 \\
\hline & & & otal & & & & & & & 281 \\
\hline & & Perc & & & & & & & & $\begin{array}{l}87,8 \\
1 \%\end{array}$ \\
\hline
\end{tabular}

Note Result:

1 = less; 2 = moderate; 3 = good; 4 = very good

$0-20 \%=$ Not feasible; $21-40 \%=$ less feasible; $41-60 \%=$ Fairly feasible; $61-80 \%=$ Eligible $; 81-100 \%=$ Very feasible 
Table 3. Test results trial the big scale of tayoga dance video development

\begin{tabular}{|c|c|c|c|c|c|c|c|c|c|c|}
\hline \multirow[t]{2}{*}{ No } & \multirow[t]{2}{*}{ NIM } & \multicolumn{8}{|c|}{ Indicator Item Values } & \multirow{2}{*}{$\begin{array}{l}\text { Scor } \\
\mathrm{e}\end{array}$} \\
\hline & & 1 & 2 & 3 & 4 & 5 & 6 & 7 & 8 & \\
\hline \multirow[t]{2}{*}{1.} & 1902013404 & & & & & & & & & \\
\hline & 7 & 3 & 3 & 3 & 3 & 4 & 3 & 3 & 3 & 25 \\
\hline \multirow[t]{2}{*}{2.} & 1902013401 & & & & & & & & & \\
\hline & 6 & 3 & 3 & 3 & 3 & 4 & 3 & 2 & 4 & 25 \\
\hline \multirow[t]{2}{*}{3.} & 1902013403 & & & & & & & & & \\
\hline & 9 & 4 & 4 & 4 & 4 & 3 & 4 & 4 & 4 & 31 \\
\hline \multirow[t]{2}{*}{4.} & 1902013407 & & & & & & & & & \\
\hline & 6 & 3 & 3 & 3 & 3 & 3 & 3 & 3 & 3 & 24 \\
\hline \multirow[t]{2}{*}{5.} & 1902013401 & & & & & & & & & \\
\hline & 3 & 3 & 4 & 3 & 3 & 3 & 4 & 3 & 3 & 26 \\
\hline \multirow[t]{2}{*}{6.} & 1802013400 & & & & & & & & & \\
\hline & 4 & 3 & 4 & 4 & 4 & 4 & 4 & 4 & 4 & 31 \\
\hline \multirow[t]{2}{*}{7.} & 1802013403 & & & & & & & & & \\
\hline & 4 & 4 & 4 & 4 & 4 & 3 & 3 & 3 & 4 & 29 \\
\hline \multirow[t]{2}{*}{8.} & 1902013400 & & & & & & & & & \\
\hline & 6 & 3 & 4 & 4 & 4 & 2 & 3 & 3 & 3 & 26 \\
\hline \multirow[t]{2}{*}{9.} & 1902013407 & & & & & & & & & \\
\hline & 1 & 2 & 3 & 2 & 2 & 3 & 3 & 3 & 3 & 21 \\
\hline \multirow[t]{2}{*}{10.} & 1902013401 & & & & & & & & & \\
\hline & 5 & 4 & 4 & 4 & 4 & 4 & 4 & 4 & 4 & 32 \\
\hline \multirow[t]{2}{*}{11.} & 1902013400 & & & & & & & & & \\
\hline & 4 & 3 & 4 & 4 & 4 & 4 & 4 & 4 & 4 & 31 \\
\hline \multirow[t]{2}{*}{12.} & 1802013404 & & & & & & & & & \\
\hline & 9 & 3 & 3 & 3 & 3 & 4 & 3 & 3 & 4 & 26 \\
\hline \multirow[t]{2}{*}{13.} & 1802013402 & & & & & & & & & \\
\hline & 5 & 3 & 3 & 4 & 4 & 4 & 4 & 3 & 4 & 29 \\
\hline \multirow[t]{2}{*}{14.} & 1902013401 & & & & & & & & & \\
\hline & 0 & 4 & 4 & 4 & 4 & 4 & 4 & 4 & 4 & 32 \\
\hline \multirow[t]{2}{*}{15.} & 1802013408 & & & & & & & & & \\
\hline & 7 & 3 & 3 & 3 & 3 & 3 & 3 & 3 & 3 & 24 \\
\hline \multirow[t]{2}{*}{16.} & 1902013400 & & & & & & & & & \\
\hline & 7 & 4 & 4 & 4 & 4 & 3 & 3 & 3 & 4 & 29 \\
\hline 17. & 1802013402 & 3 & 3 & 3 & 3 & 3 & 3 & 3 & 3 & 24 \\
\hline
\end{tabular}

\begin{tabular}{|c|c|c|c|c|c|c|c|c|c|c|}
\hline & 6 & & & & & & & & & \\
\hline \multirow[t]{2}{*}{18.} & 1902013406 & & & & & & & & & \\
\hline & 1 & 4 & 4 & 4 & 4 & 4 & 4 & 4 & 4 & 32 \\
\hline \multirow[t]{2}{*}{19.} & 1902013406 & & & & & & & & & \\
\hline & 1 & 4 & 4 & 4 & 4 & 4 & 4 & 4 & 4 & 32 \\
\hline \multirow[t]{2}{*}{20.} & 1902013402 & & & & & & & & & \\
\hline & 3 & 3 & 4 & 3 & 3 & 4 & 3 & 3 & 4 & 27 \\
\hline \multirow[t]{2}{*}{21.} & 1802013403 & & & & & & & & & \\
\hline & 9 & 3 & 4 & 4 & 4 & 3 & 4 & 3 & 4 & 29 \\
\hline \multirow[t]{2}{*}{22.} & 1902013401 & & & & & & & & & \\
\hline & 4 & 3 & 4 & 4 & 4 & 3 & 3 & 3 & 4 & 28 \\
\hline \multirow[t]{2}{*}{23.} & 1802013400 & & & & & & & & & \\
\hline & 6 & 3 & 4 & 3 & 3 & 3 & 4 & 3 & 4 & 27 \\
\hline \multirow[t]{2}{*}{24.} & 1802013400 & & & & & & & & & \\
\hline & 8 & 3 & 4 & 3 & 3 & 4 & 4 & 3 & 4 & 28 \\
\hline \multirow[t]{2}{*}{25.} & 1902013400 & & & & & & & & & \\
\hline & 3 & 4 & 4 & 4 & 4 & 4 & 4 & 4 & 4 & 32 \\
\hline \multirow[t]{2}{*}{26.} & 1802013402 & & & & & & & & & \\
\hline & 6 & 3 & 3 & 3 & 3 & 3 & 3 & 3 & 3 & 24 \\
\hline \multirow[t]{2}{*}{27.} & 1902013408 & & & & & & & & & \\
\hline & 5 & 3 & 4 & 2 & 2 & 3 & 4 & 4 & 3 & 25 \\
\hline \multirow[t]{2}{*}{28.} & 1802013406 & & & & & & & & & \\
\hline & 2 & 4 & 3 & 4 & 4 & 4 & 4 & 4 & 4 & 31 \\
\hline \multirow[t]{2}{*}{29.} & 1802013403 & & & & & & & & & \\
\hline & 3 & 4 & 4 & 4 & 4 & 4 & 4 & 4 & 4 & 32 \\
\hline \multirow[t]{2}{*}{30.} & 1802013409 & & & & & & & & & \\
\hline & 2 & 3 & 4 & 3 & 4 & 4 & 4 & 3 & 4 & 29 \\
\hline \multirow[t]{2}{*}{31.} & 1902013400 & & & & & & & & & \\
\hline & 8 & 2 & 3 & 3 & 3 & 3 & 3 & 3 & 3 & 23 \\
\hline \multirow[t]{2}{*}{32.} & 1802013400 & & & & & & & & & \\
\hline & 9 & 3 & 4 & 3 & 3 & 4 & 4 & 4 & 4 & 29 \\
\hline \multirow[t]{2}{*}{33.} & 1802013404 & & & & & & & & & \\
\hline & 6 & 3 & 3 & 3 & 4 & 3 & 4 & 4 & 3 & 27 \\
\hline \multirow[t]{2}{*}{34.} & 1802013404 & & & & & & & & & \\
\hline & 6 & 3 & 3 & 3 & 4 & 3 & 4 & 4 & 3 & 27 \\
\hline \multirow[t]{2}{*}{35.} & 1902013402 & & & & & & & & & \\
\hline & 4 & 3 & 4 & 3 & 3 & 3 & 3 & 3 & 3 & 25 \\
\hline \multirow[t]{2}{*}{36.} & 1802013403 & & & & & & & & & \\
\hline & 7 & 3 & 3 & 3 & 3 & 3 & 3 & 3 & 3 & 24 \\
\hline
\end{tabular}




\begin{tabular}{|c|c|c|c|c|c|c|c|c|c|c|}
\hline 37. & $\begin{array}{c}1902013407 \\
0\end{array}$ & 3 & 4 & 4 & 4 & 2 & 4 & 4 & 4 & 29 \\
\hline 38. & $\begin{array}{c}1902013403 \\
1\end{array}$ & 2 & 4 & 4 & 4 & 2 & 4 & 4 & 3 & 27 \\
\hline 39. & $\begin{array}{c}1902013405 \\
5\end{array}$ & 4 & 4 & 4 & 4 & 4 & 4 & 4 & 4 & 32 \\
\hline 40. & $\begin{array}{c}1902013408 \\
7\end{array}$ & 3 & 3 & 4 & 4 & 3 & 3 & 3 & 3 & 26 \\
\hline 41. & $\begin{array}{c}1902013408 \\
8\end{array}$ & 2 & 3 & 2 & 2 & 3 & 3 & 3 & 3 & 21 \\
\hline 42. & $\begin{array}{c}1902013406 \\
2\end{array}$ & 3 & 3 & 4 & 4 & 3 & 3 & 3 & 3 & 26 \\
\hline 43. & $\begin{array}{c}1902013406 \\
3 \\
\end{array}$ & 3 & 4 & 4 & 4 & 4 & 4 & 4 & 4 & 31 \\
\hline 44. & $\begin{array}{c}1902013406 \\
5\end{array}$ & 2 & 3 & 3 & 2 & 3 & 3 & 3 & 3 & 22 \\
\hline 45. & $\begin{array}{c}1902013400 \\
4\end{array}$ & 3 & 4 & 4 & 4 & 4 & 4 & 4 & 4 & 31 \\
\hline \multicolumn{10}{|c|}{ Total } & 1268 \\
\hline \multicolumn{10}{|c|}{ Percentage } & $\begin{array}{c}88,0 \\
5 \%\end{array}$ \\
\hline
\end{tabular}

Note Result:

$1=$ less; 2 = moderate; 3 = good 4 = very good

$0-20 \%=$ Not feasible $; 21-40 \%=$ less feasible; $41-60 \%=$ Fairly feasible; $61-80 \%=$ Eligible; $81-100 \%=$ Very feasible

\section{CONCLUSION}

The conclusions of this paper are 1) there are obstacles to the online learning process regarding practice, namely students have different interpretations of the video presented, so it requires time and a separate evaluation schedule. Limited time, unable to schedule evaluation. Even though there are obstacles, the development process is running smoothly. The development process is carried out based on the development parts that have been compiled; 2) the value of the quality of the development content is $91.06 \%$ and the media presentation is $94.44 \%$, which means that this product is very suitable for use; 3 ) the value in the smallscale trial was $87.81 \%$, while the large-scale trial was $88.05 \%$. The average value of student learning outcomes before and after using the media has increased significantly so that this video is effectively used.

\section{ACKNOWLEDGMENTS}

This research is supported by the university's funding through the PNBP research grant, under the coordination of Institute of Research and Community Services, Universitas Negeri Surabaya.

\section{REFERENCES}

[1] Anastasia, Citra Agusta Putri, editor, "Begini Awal Mula Virus Corona Bisa Masuk ke Indonesia." Tribunnews.com (https://www.tribunnews.com/nasional/2020/03/02/ begini-awal-mula-virus-corona-bisa-masuk-keindonesia), 2020.

[2] Faqih, Abdullah, "Update Virus Corona di Surabaya \& Jatim, Sabtu 18 April 2020, 522 Kasus, Pasar Kapasan Buka Kembali." (https://surabaya.tribunnews.com/2020/04/18/updat e-virus-corona-di-surabaya-jatim-sabtu-18-april2020-522-kasus-pasar-kapasan-buka-kembali), 18 April 2020.

[3] Murgiyanto, Sal., Koreografi: Pengetahuan Dasar Komposisi Tari, Jakarta: Proyek Pengadaan Buku Pendidikan Menengah Kejuruan Direktorat Jenderal Pendidikan Dasar dan Menengah Departemen Pendidikan dan Kebudayaan, 1983, pp. 3-4.

[4] Gie, The Liang, Filasafat Keindahan, Yogyakarta: Pusat Belajar Ilmu Berguna (PUBIB), 1996, pp. 49. 50.

[5] Hayes, Elizabeth R., Dance Composition and Production, New York : The Ronald Press Company, 1955, pp. 11-19.

[6] Meri, La, Elemen-elemen Dasar Komposisi Tari, Terjemahan Soedarsono. Yogyakarta: Lagaligo, 1986, p. 83.

[7] Smith, Jacqueline, Komposisi Tari: Sebuah Petunjuk Praktis Bagi Guru, Terjemahan Ben Suharto, Yogyakarta: Ikalasti Yogyakarta, 1985, pp. 74-75.

[8] Humphrey, Doris. Seni Menata Tari, terjemahan Sal Murgiyanto, Jakarta: Dewan Kesenian Jakarta, 1983, p. 57. 
[9] Suhardana, K.M., Yama Niyama Brata. Surabaya: Paramita, 2007, pp. 74-75.

[10] Anandamitra, Avadhutika Acarya, Meditasi: Melampaui Batas Kesadaran Supra, Jakarta: Persatuan Ananda Marga Indonesia, 1990, p.49.

[11] , pp. 44-45.

[12] Sarasvati, Svami Satyananda, Surya Namaskara: Sebuah Teknik Penguatan Tenaga Matahari dalam Yoga, I Wayan Maswinara, editor, Dewi Saraswati, penterjemah, Surabaya: Paramita, 2002, pp. 15-28.

[13] Suwidnya, I Gede, "Pengembangan Model Pembelajaran Menabuh Gamelan Gender Wayang
Bali Dengan Teknik Belajar Siti Playing,Tesis Universitas Negeri Surabaya, Surabaya, 2014, p. 70.

[14] Munadi, Yudhi, Media Pembelajaran Sebuah Pendekatan Baru, Jakarta: Referensi, 2013, p. 127

[15] Sugiyono, Metode Penelitian Pendidikan: Pendekatan Kuantitatif, Kualitatif dan R\&D, Bandung: Alfabeta, 2014, p. 407.

[16] Thiagaradjan, Instructional Development for Training Teacher of Exeptional Children, Bloomington: Indiana University, 197 